\title{
Mathematics Instruction to Promote Mathematics Higher-Order Thinking Skills of Students in Indonesia: Moving Forward
}

\author{
Benidiktus Tanujaya ${ }^{1}$, Rully Charitas Indra Prahmana ${ }^{2}$, Jeinne Mumu ${ }^{1}$ \\ ${ }^{1}$ Universitas Papua, Jl. Cenderawasih 84, Manokwari, Papua Barat, Indonesia \\ ${ }^{2}$ Universitas Ahmad Dahlan, Jl. Pramuka 42, Pandeyan, Yogyakarta, Indonesia
}

\begin{abstract}
HOTS instruction in mathematics is rarely explicitly programmed by the schoolteacher. As a result, students' HOTS is at the lowest level, especially in national or international assessments. The purpose of this research is to determine why mathematics education in Indonesia does not have a significant effect on student HOTS by conducting a review of several Indonesian publications on the subject. This research is a qualitative method of literature review related to the HOTS of Indonesian mathematics students, and an organized interview triangulated to support the data and information from the literature review. The interview consisted of two critical questions administered using Google Form: implementing active learning and mathematics textbooks on mathematics classroom activities. The results concluded that there were two primary sources of error in mathematics learning to increase HOTS in Indonesia: active learning and current mathematics textbooks. Besides, in teaching and learning practices, the active learning model is rarely used when using official texts that do not promote HOTS for mathematics students in Indonesia.
\end{abstract}

Keywords - higher-order thinking skills, active learning, mathematics textbook, literature review

DOI: $10.18421 /$ TEM104-60

https://doi.org/10.18421/TEM104-60

Corresponding author: Rully Charitas Indra Prahmana, Universitas Ahmad Dahlan, Yogyakarta, Indonesia.

Email: rully.indra@mpmat.uad.ac.id

Received: 10 August 2021.

Revised: 14 November 2021.

Accepted: 20 November 2021.

Published: 26 November 2021.

(c) BY-NC-ND (C) 2021 Benidiktus Tanujaya, Rully Charitas Indra Prahmana \& Jeinne Mumu; published by UIKTEN. This work is licensed under the Creative Commons Attribution-NonCommercial-NoDerivs 4.0 License.

The article is published with Open Access at www.temjournal.com

\section{Introduction}

The development of students' higher-order thinking skills (HOTS) is an international priority for education [1], through which students can train themselves to face the demands of a modern age, the digital revolution 4.0. According to Saavedra and Opfer [2], the need for HOTS among the students in the 21 st century as a necessity for the progress of this initiative is an imperative as a result of globalization, technical developments, globalization, international rivalry, evolving economies, and global challenges in the environment and politics.

All facets of life in the 21st century require highly qualified individuals, including mathematical education graduates [3]. They should be capable of thinking analytically, objectively, and creatively. With these capacities, they can handle development and changing times. Furthermore, they are expected to overview the issues, analyze them, and quickly provide solutions. Lastly, they are building hope for the future of Indonesian society. Consequently, the graduates of mathematics education must possess excellent thinking abilities, particularly higher-order thinking skills (HOTS).

As a skill, HOTS of college graduates rely on their thinking skills developed during their primary and secondary school years. Therefore, the Indonesian government continues to strive to develop student's HOTS, especially through mathematics instruction in primary and secondary school. Some of the government's initiatives are to implement HOTSbased curricula, including the 2006 curriculum (KTSP) and the 2013 curriculum, as outlined in the 'standard content' in mathematics instruction. Both curricula state that the purpose of studying mathematics in Indonesia is to develop students' HOTS, including critique, creativity, communication, and collaboration. This means that for 14 years, the Indonesian government has sought to develop HOTS for students in mathematics learning. 
Consequently, it is necessary to recognize the relationship between the curricular implementation and students' HOTS. Several possible questions include the following: is there an increase in student HOTS as a result of the two curricula' implementation in Indonesia? Does the application of the HOTS-based curriculum have a positive effect on the HOTS of mathematics students? If the implementation has little effect on students' HOTS, what are the variables that contribute to this?

Specifically, there has been no systematic study of the relationship between the application of Indonesia's national curriculum and the HOTS of mathematics students. Research on HOTS of mathematics students in Indonesia has not been conducted nationally. The research was only conducted at certain schools with a limited number of samples. However, HOTS for mathematics students in Indonesia can be learned from survey reports by several international institutions such as PISA and TIMMS [4]. Although the fact that HOTS and thinking skills assessed by PISA are slightly different.

PISA is the OECD's Programme for International Student Assessment. PISA measures 15-year-olds' ability to use their reading, mathematics and science knowledge and skills to meet real-life challenges. Therefore, this test is not intended to assess student mastery of curriculum content, but rather to learn whether students can apply the knowledge they have learned in situations encountered in daily life. PISA scores used to measure student thinking skills in solving mathematics problems. Problem-solving, on the other hand, is one of the four components of HOTS. As a result, the PISA findings can be utilized to provide information on the accomplishments of Indonesian mathematics students as a result of the implementation of the KTSP curriculum and K-13 curricula. The data shown in Table 1. indicate the results of PISA in recent years.

Table 1. PISA Results about mathematics performance in Indonesia

\begin{tabular}{ccccccc}
\hline No & Year & $\begin{array}{c}\text { Mean } \\
\text { Score }\end{array}$ & Rank & $\begin{array}{c}\text { Partici- } \\
\text { pant }\end{array}$ & \multicolumn{2}{c}{$\begin{array}{c}\text { Student } \\
\text { achievement (\%) }\end{array}$} \\
\hline 1 & 2003 & 362.2 & 38 & 40 & & \multicolumn{2}{c}{$\begin{array}{c}\text { Level } \\
\text { 5 or 6 }\end{array}$} & $\begin{array}{c}\text { Below } \\
\text { level 2 }\end{array}$ \\
\hline 2 & 2006 & 399.0 & 48 & 56 & & \\
3 & 2009 & 371.0 & 61 & 65 & & \\
4 & 2012 & 375.0 & 64 & 65 & 0.30 & 75.70 \\
5 & 2015 & 386.0 & 65 & 72 & 0.90 & 42.30 \\
6 & 2018 & 379.0 & 74 & 79 & 0.60 & 51.70 \\
\hline
\end{tabular}

Sources: PISA Reports: $2003-2018$.

Table 1. shows that from 2003 to 2018 , the average increase in scores of 2 was non-significant. If the analysis started in 2006, when the KTSP curriculum is implemented, the average student score seemed to have decreased. The information shown on the scores indicates that there is something wrong with the implementation of mathematics instruction in Indonesia. This information indicates that the government of Indonesia still needs to work towards achieving the global objectives of quality education, as set out in the UN Sustainable Development Goals for Education for 2030.

The low level of mathematics education in Indonesia can also be noted in relation to PISA student scores in other countries. Indonesian students have always been at the bottom of the PISA list (see Table 1.). Over the years, Indonesia's position has not changed to the middle class, let alone increase to the top level, as in other Asian countries such as Singapore, Taiwan, and China (Shanghai).

Table 1. also presents that only a small group of mathematics students are at the highest level of PISA. The proportion of students who are at level 5 or 6 is less than $1 \%$. Level 5 of PISA according to OEDC is that students can develop and work with models for complex situations, identifying constraints and specifying assumptions. They can select, compare, and evaluate appropriate problem-solving strategies for dealing with complex problems related to these models. Students at this level can work strategically using broad, well-developed thinking and reasoning skills, appropriately linked representations, symbolic and formal characterizations, and insight pertaining to these situations. Therefore, they can reflect on their actions and formulate and communicate their interpretations and reasoning.

Furthermore, Table 1. offers information that most Indonesian students are less skilled in mathematical thought. Students are only able to answer questions at level 2, involving familiar situations in which all relevant information is provided, and the questions are clearly defined. They can only recognize details and obvious problems, execute repetitive procedures according to direct instructions. Lastly, level 2 is regarded as a fundamental level of mathematical proficiency at which students begin to show the types of skills required to engage in active mathematics use.

The weakness of Indonesian students results in the PISA 2015 mathematics survey and the previous year led the decision by the Ministry of Education of Indonesia to put more emphasis on HOTS inclusion of curricula beginning in 2018. This latest rule highlights the importance of developing a shared knowledge of HOTS in mathematics across several levels, including curriculum, pedagogy, and assessment, as well as among students, teachers, and policymakers [4]. As a result of this policy, the government through the ministry of education and culture held a HOTS-based Mathematics National Examination [5]. The results of the National Examination 2018, as published by the Centre of Education Assessment, are presented in Figure 1. 


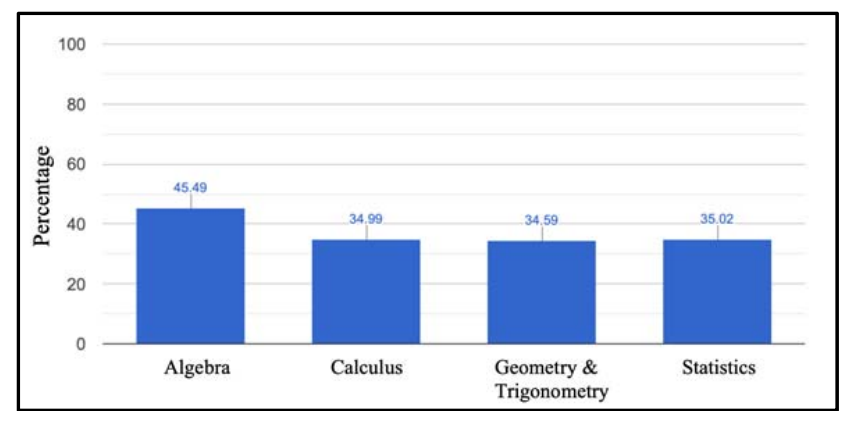

Figure 1. The percentage of students answered correctly based on the content in Mathematics

Based on Figure 1., the percentage of high school students who correctly answered mathematics problems on the National Exam was less than 50\%. Most students who took the 2018 national exam were unable to correctly answer mathematics problems. The statistics raise alarms about the condition of mathematics education in Indonesia. To increase the quality of mathematics education in Indonesia, a concerted effort, not simply rhetoric, is required.

To address the issue of low-quality mathematics education in Indonesia, it is necessary to understand what has been accomplished in the subject of mathematical education in Indonesia. Based on this knowledge, any necessary steps, as well as what should not be done and what should be improved, can be taken. Is it true that the objectives of mathematics education in the curriculum are generating the expected results? Are there any sources of error in the curriculum's implementation? What procedures should be done to ensure the curriculum's implementation produces the anticipated results?

However, before deliberating on the HOTS of mathematics students in Indonesia, because of the implementation of the national curriculum, we provide information about the HOTS and its relation to taxonomy of Bloom and other thinking skills. What exactly is HOTS? How do we measure it? What function does it play in students' performance with mathematics? And anything else relevant to HOTS.

\section{Taxonomy Bloom, HOTS, and other thinking skills}

The taxonomy of Bloom is a classification system used to identify and distinguish various phases of human cognition. The hierarchical ordering of cognitive skills consists of remembering, understanding, applying, analyzing, evaluating, and creating, which is divided into two groups of thinking skills. The top of the scale is frequently known as LOTS - lower-order thinking skills, whereas the ones at the end are regarded as higherorder thought skills (HOTS). Regarding Bloom taxonomy, HOTS includes the cognitive dimension of analyzing, evaluating, and creating. Both thinking skills can be recognized when each occur [6].

On the other hand, HOTS is comprised of several thinking skills. HOTS consists of critical, creative, and systematics thinking skills [7]. In this regard, critical and creative thinking skills are two principal dimensions of HOTS [8]. Critical thinking skills are the cognitive ability to analyze and evaluate, while creative thinking is related to creating in the taxonomy of Bloom.

Creative thinking is trying to construct something new, while critical thinking is trying to evaluate value or validity in something that exists. Creative thinking is done by infringing accepted principles, while critical thinking is done through the application of accepted principles. Although they are not the same thing, creative and critical thinking is different sides of the same coin [9]. This indicates that critical thinking skills and creative thinking skills need to be studied in a balanced learning environment.

HOTS is also known as a cognitive skill consisting of four components of thinking skills: reasoning skills, argumentation skills, problem-solving \& critical thinking, and metacognition. The abilities are regarded as a fundamental cognitive tool that facilitates in adaptability and the achievement of good intellectual and behavioral outcomes [9]. Reasoning skills involve both deductive and inductive reasoning processes. Deductive reasoning involves using facts, arguments, or evidence to establish a conclusion, while inductive reasoning is a method through which a verifiable conclusion is adapted to a new circumstance [10].

Argumentations are a critical component of thinking skills because they enable individuals to make assertions, collect and analyze evidence, and integrate numerous sources of information to support a claim [11]. The arguments can range from simple to exceedingly complicated, at least four distinct categories exist. A straightforward argument is composed of a single premise and a single claim. A complicated argument is composed of several premises and a single claim. A chain argument begins with one premise and progresses to a second premise and finally to a claim. These arguments make use of a causal chain in their reasoning [5].

Metacognition is most succinctly stated as "thinking about thinking." Metacognition is divided into two parts: knowledge and regulation. Metacognitive knowledge includes understanding oneself as a learner and the circumstances that may affect performance, as well as knowledge of methods and when and why to utilize them. Metacognitive regulation is the process of monitoring one's cognition. It encompasses activity planning, awareness of comprehension and task performance, and assessment of the efficacy of monitoring 
processes and techniques. Metacognition is a term that refers to HOTS that entail intentional regulation of the cognitive processes that occur during learning. Therefore, metacognition is crucial for effective learning [12].

Moreover, HOTS can be conceived as a complex, non-algorithmic way of thinking that often generates multiple solutions. In fact, HOTS is one of the key aspects of education. As the highest level in the cognitive process hierarchy, students' HOTS will perform when they encounter unfamiliar problems, uncertainties, dilemmas, or new information. When faced with the situation, students keep it in mind, compile facts, link it to previous knowledge, and generate this information to achieve a goal or solve the complicated situation [13]. Consequently, many researchers and educators concluded that higherorder thinking skills were the same as the difficulty of the issues. Complexity can be one aspect of HOTS, but it is not the only aspect of HOTS [14].

HOTS encourage students to interpret, analyze, or manipulate information. Using these thinking skills, students are allowed to excel and attain intellectual freedom. HOTS, therefore, enables students to overcome the challenges of too much information in this information age, but there is limited processing time [12]. HOTS is a thought-provoking skill that mathematics students need after graduation to face the real world. Without HOTS, mathematics students will no longer be able to compete with other students [4].

There are several research questions regarding students' HOTS in Indonesia, such as how the students HOTS who studied mathematics in Indonesia. Furthermore, is there a significant development of students' HOTS in Indonesia due to the implementation of the curriculum KTSP, which was then "improved" through the performance of the curriculum 2013? What are the factors supporting the development of students thinking skills? If it does not work, then what factors cause it? Therefore, research into mathematics instruction in Indonesia needs to be carried out to answer these questions, particularly enhancing students' HOTS.

\section{Methodology}

The research was carried using the qualitative research method through literature review and interview approaches. The two approaches are known as triangulation by method or multimethod triangulation for increasing internal validity in the qualitative method [15]. A literature review was performed on papers published in scientific journals, which concerns efforts to develop HOTS for mathematics student in Indonesia. Meanwhile, the interview was conducted to validate the findings of the literature review.

The review of the literature was conducted to analyze articles that investigated HOTS in Indonesian mathematics instruction. The articles were gathered purposefully in several steps. The first step is to identify trustworthy mathematics education journals published in Indonesia, particularly those that are indexed by Sinta. Sinta - Science and technology index - is the official portal of the Indonesian that measures the performance of science and technology, including the performance of researchers, authors, and journals. These journals were chosen because of two criteria. First, the scope of their publications encompasses a wide spectrum of research in mathematics education, and second, they are all open journals so that they are accessible to researchers. As a result, the Sinta 1 and Sinta 2 indexed journals were chosen. There is one mathematics education journal indexed in Sinta 1 and nine Sinta 2 indexed mathematics education journals that have been listed.

The next step was to collect articles about Indonesian students' mathematics HOTS in the identified journals. Keywords that are used to identify HOTS documents include HOTS, high-order thinking skills, creative thinking, and critical thinking. In addition, relevant HOTS documents that have been published in other journals have also received attention, but the identification and thus inclusion of these papers has been primarily through Google Scholar search engine, not directly from the journals. Based on these criteria, several articles were discovered in national and international journals discussing HOTS in Indonesian mathematics education. Table 2. shows the sources of literature reviewed in this study, which clearly demonstrates the rapid growth of research interest and findings in this field over the last three years.

Table 2. Sources of literature review for this research

\begin{tabular}{|c|c|c|c|c|c|c|c|}
\hline \multirow{2}{*}{ Publication } & \multicolumn{6}{|c|}{ Publication Year } & \multirow{2}{*}{ Total } \\
\hline & $<2016$ & 2016 & 2017 & 2018 & 2019 & 2020 & \\
\hline $\begin{array}{l}\text { Accredited } \\
\text { Indone-sia } \\
\text { Journal }\end{array}$ & 5 & 4 & 1 & 1 & 10 & 5 & 26 \\
\hline $\begin{array}{l}\text { Another } \\
\text { Indone-sia } \\
\text { Journal }\end{array}$ & - & 1 & 2 & 9 & 3 & - & 15 \\
\hline $\begin{array}{l}\text { Interna- } \\
\text { tional } \\
\text { Journal }\end{array}$ & 1 & 1 & 3 & 9 & - & - & 14 \\
\hline Total & 5 & 6 & 6 & 19 & 13 & 5 & 55 \\
\hline
\end{tabular}

Moreover, the researcher interviewed by using Google Form. The interview is a technique for increasing the internal validity of the findings of the literature review. The interview questions were 
therefore developed after a study of the literature. The questions raised concern the active learning approach and the textbooks on mathematics for school instruction. Some of them are questions with multiple choices, and the others are open-ended questions.

The respondents who participated in the study amounted to 385 individuals. The average is 11.32 respondents for each province, and the standard deviation is 10.22 , while the minimum is 1 and the maximum is 40 . They are mathematics teachers from elementary, junior high, senior high, and vocational school. They consist of mathematics teachers with 275 Bachelor's degrees, 98 Master's degrees, and 12 doctoral backgrounds. They are public and private employees, with the lowest to highest ranks from the entire territory of Indonesia.

The distribution of the number of mathematics teachers as respondents in the Indonesian archipelago is presented in Figure 2.

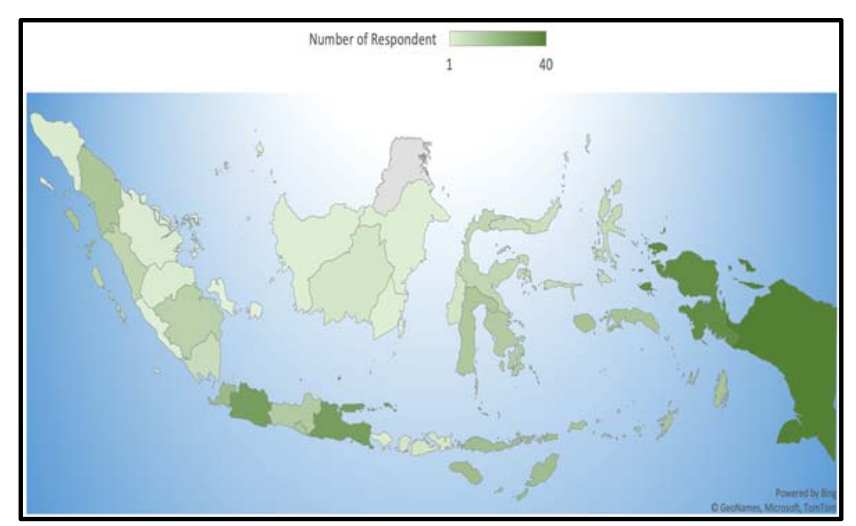

Figure 2. Distribution of respondents by provinces in Indonesia

Figure 2. indicates that respondents are scattered across 34 provinces of Indonesia archipelago country. The largest number of respondents were concentrated in three provinces, namely Papua, West Papua, East Java, and West Java.

\section{Results and Discussion}

This research is divided into two stages: the analysis of scientific articles and the interviewing of mathematics teachers. The findings of the literature review will be confirmed through interviews with a representative sample of mathematics teachers across Indonesia.

\subsection{HOTS research on Mathematics students in Indonesia}

Based on the research, the scientific articles on mathematics students' HOTS capabilities in Indonesia can be classified into three categories: (1) assessing students' HOTS competence, (2) the availability of HOTS-supporting tools, and (3) developing students' HOTS in mathematics instruction. The following section discusses the three research categories in detail.

\subsubsection{Assessing students' HOTS competence}

These studies were conducted in the first category to ascertain students' HOTS competence with regards to mathematics instruction. Three domains of students' HOTS competencies are examined: cognitive, affective, and psychomotor. The research focuses on students' HOTS cognitive abilities, which include ability [4], readiness [5], knowledge [16], and capabilities [17]. The research examines students' HOTS affective abilities, such as perception, as well as their HOTS psychomotor abilities, which includes several studies on HOTS error detection and thinking skills, such as the symbolic representation error [18] and the algebraic thinking process [19]. Another area of research involving HOTS competencies is the relationship between HOTS and other variables such as academic success and gender [20].

This research is preliminary studies on students' HOTS competencies. The research aims to elicit data on the HOTS competence of Indonesian mathematics students. The findings from research on competencies, specifically students' attitudes, knowledge, and abilities regarding HOTS, are used to conduct future research and to design mathematics instruction.

\subsubsection{The availability of HOTS-supporting tools}

In the second classification, researchers analyzed the availability of various test instruments and learning resources as the main component to develop the HOTS of mathematics students. The researchers learnt about the availability of learning resources that support students HOTS. For example, the development of instruments and assessing of students HOTS [21]. Another study related to this category is about HOTS problems in mathematics textbooks [22].

The purpose of these studies is to examine the availability of HOTS-based learning resources, as well as efforts to develop learning resources tailored to the characteristics of Indonesian mathematics students. The findings indicated that there were limited HOTS-based learning resources available for teachers and students to use in order to help students develop their HOTS.

Is mathematics taught using a limited HOTS-based learning resource? Are mathematics textbooks and student activity sheets not HOTS-based? The information gleaned from the analysis of scientific articles will be corroborated through interviews with 
mathematics teachers from across Indonesia. In other words, triangulation will be used to ensure the research findings' validity.

\subsubsection{Developing students' HOTS in Mathematics instruction}

In the third category, the researchers used several efforts, including the implementation of different learning models, learning media, and learning tools, to increase the students' HOTS in mathematics classroom. These categories studied about learning models and instruments were designed for the improvement of HOTS mathematics students. Learning models are classified as active learning, including cooperative learning, discovery learning [23], problem-based learning [24], problem-solving [25], and other constructivism-based learning realistic mathematics education, contextual teaching learning, and open-ended approaches [26]. The research also includes the implementation of learning tools [27], open problem assessment [28], and student activity sheets [29].

The reason for this category of research is that conventional mathematics instruction has failed to develop students' HOTS. On the other hand, various instructional models can be used to help students improve their HOTS. As a result, various instructional models are used to help students improve their HOTS. The findings indicated that these various instructional models contributed positively to students' HOTS improvement.

Is it true that the learning models used in these various studies are rarely used in mathematics teaching and learning? Why aren't these models implemented in mathematics classes? These two questions, as well as several others, will be addressed through interviews with several Indonesian mathematics teachers.

\subsection{HOTS and Active Learning in Mathematics instruction of Indonesia}

Student success in mathematics education depends on several factors, one of which is the use of an effective learning model in the classroom. Pursuing educational excellence through classroom instruction is not a new idea in school mathematics. According to Chen and $\mathrm{Li}$ [30], the quality of classroom instruction matters the most for improving students' performance.

Instruction based on active learning plays a significant role in fostering students' HOTS [31]. Several studies report that these learning models play an important role in developing HOTS mathematics students. The learning model includes project-based learning, problem-based learning, inquiry learning, and discovery learning. Active learning, which is part of constructivism, is a learning model that is commonly used to improve HOTS students in Indonesia. The survey indicated that most Indonesian mathematics teachers implemented an active learning model, as shown in Table 3.

Table 3. Frequency of implementation of the active learning model in Mathematics instruction

\begin{tabular}{lccccc}
\hline Learning & \multicolumn{5}{c}{ Frequency of Implementation (\%) } \\
\cline { 2 - 6 } Model & Always Frequently Occasionally Seldom & Never \\
\hline $\begin{array}{l}\text { Problem- } \\
\text { based }\end{array}$ & 4.16 & 38.18 & 21.82 & 33.25 & 2.60 \\
$\begin{array}{l}\text { Learning } \\
\begin{array}{l}\text { Project-base } \\
\text { Learning }\end{array}\end{array}$ & 2.34 & 13.25 & 34.55 & 34.55 & 15.32 \\
$\begin{array}{l}\text { Inquiry } \\
\text { Learning }\end{array}$ & 4.68 & 30.65 & 26.23 & 26.23 & 12.21 \\
$\begin{array}{l}\text { Discovery } \\
\text { Learning }\end{array}$ & 6.75 & 37.14 & 22.34 & 26.23 & 7.53 \\
\hline \multicolumn{1}{c}{ Average } & 4.48 & 29.81 & 26.23 & 30.07 & 9.41 \\
\hline
\end{tabular}

Table 3. provides information that only a small proportion of mathematics teachers have never used an active learning model. This indicates that active learning is a common learning model for Indonesian mathematics teachers. However, only a small proportion of mathematics teachers use it in their learning activities when it is based on the frequency of implementation. There are less than $5 \%$ of mathematics teachers who always apply an active learning model in their classrooms.

The findings of this survey are consistent with the analysis of the literature analysis. Active learning is a learning paradigm that is implemented as an alternative to the conventional learning model. These learning models are used in research to improve the learning outcomes of mathematics students, such as: Problems Based learning [32], Project-based Learning [33], Inquiry Learning [34], and Discovery Learning [35]. In other words, Indonesia's mathematics teachers seldom use active learning in regular teaching activities.

Teaching and learning mathematics in Indonesia are still traditional and appears to be mechanistic [36]. The teaching of mathematics did not emphasize the development of reasoning, logic and thought processes for students. Mathematics teaching is dominated by the implementation of verbal formulas and definitions, without paying adequate attention to student understanding. Students just listen, then imitate, or copy what the teacher does without initiative. Students are not expected to develop their own thinking skills. Students are not allowed or encouraged to maximize their ability to improve their reasoning. Mathematics learning in Indonesia should be based on active learning. 
Therefore, the application of the K-13 curriculum must be immediately adjusted based on the purposes of studying Indonesian mathematics. Why are Indonesian mathematics teachers seldom engaged in active mathematics instruction?

\subsection{HOTS of Mathematics Students and Mathematics Textbook}

Textbooks are equally valuable tools for all classes - for students to study mathematics and for teachers to prepare and teach mathematics lessons [37]. The textbooks are the core aspects of teaching and learning in the classroom. The textbooks are a representation of the curriculum of teachers and students, as a major conveyor of the curriculum [38]. Mathematics textbooks have a profound effect on the curriculum implemented [39]. Therefore, curriculum transformation was always performed in the textbook [40].

Textbooks, due to their significance as guidelines for teaching and learning in classroom activities, have a long history as topics of research [41]. The textbooks, as primary written teaching materials, are essential tools for the understanding of education policy [42], to understand past and present mathematics education [43]. Therefore, the analysis of the mathematics textbook to determine the implementation of the mathematics curriculum in Indonesia is one aspect that needs to be assessed. The results of the survey indicate that in their classroom activities, most mathematics teachers in Indonesia depend on official textbooks, as provided in Figure 3.

Figure 3. presented information that the official textbook is a critical resource for studying mathematics in Indonesia. Most of the participants $(89.1 \%)$ indicated that they used official textbooks as their learning resource. As the primary learning resource, official textbooks are used in several teaching and learning activities, as seen in the data presented in Table 4.

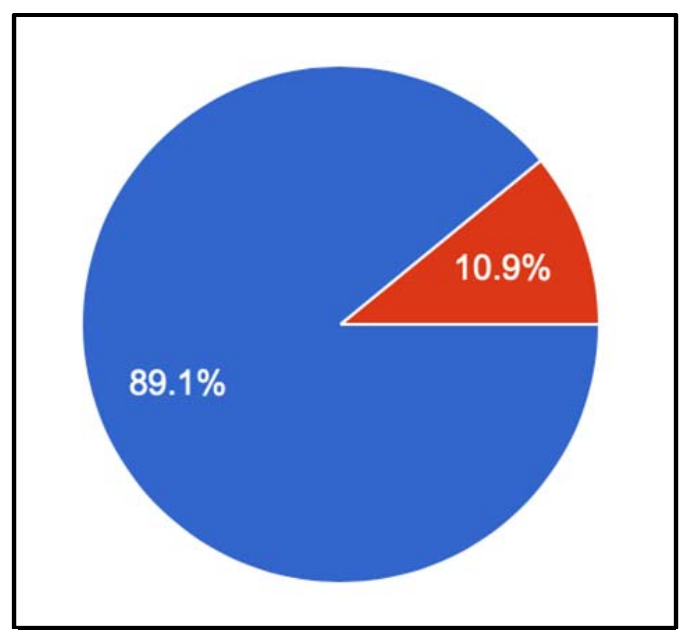

Figure 3. The proportion of Mathematics teachers using official textbooks for lessons
Table 4. indicates that the problems in the official textbook are the key guides for Indonesian mathematics teachers in the implementation of classroom activities. These problems are used as questions to provide examples, exercises, and homework. As a result, the questions in the official textbook have a significant role to play in determining the progress of students in resolving HOTS issues in Indonesia.

Table 4. Frequency of using official textbook in mathematics instruction

\begin{tabular}{lccccc}
\hline Learning & \multicolumn{5}{c}{ Frequency of Implementation (\%) } \\
\cline { 2 - 6 } Activity & AlwaysFrequently Occasionally Seldom & Never \\
\hline $\begin{array}{l}\text { Teaching } \\
\text { procedures }\end{array}$ & 239 & 41.8 & 15.7 & 17.3 & 1.1 \\
$\begin{array}{l}\text { Question as } \\
\text { example }\end{array}$ & 20.5 & 55.1 & 11.4 & 12.0 & 2.0 \\
$\begin{array}{l}\text { Question as } \\
\text { exercise }\end{array}$ & 20.7 & 56.6 & 10.9 & 10.4 & 1.3 \\
$\begin{array}{l}\text { Question as } \\
\text { home work }\end{array}$ & 17.6 & 46.3 & 16.8 & 17.8 & 1.6 \\
\hline Average & 20.6 & 49.9 & 13.7 & 14.3 & 1.5 \\
\hline
\end{tabular}

Unfortunately, some studies on mathematics textbooks have concluded that mathematics learning resources based on HOTS are not available in Indonesia. The textbooks and student activity sheets used in classrooms tends to emphasize the memorization of concepts. Students are not encouraged to think independently and creatively. Current textbooks on mathematics do not include problem-solving issues that are integrated with real life [44].

Most mathematics problems are related to the ability to apply mathematical formulas, procedures, or algorithms. There were not enough mathematical problems to inspire students to improve their analytical, evaluative, and creative skills [5]. In other words, when learning to use memorization exercises, students are not engaged in the study of mathematics but are subject to teacher orthodoxy. As a result, students are at risk of learning stagnation [45]. This is in line with the statement of Rezat [46], which notes that the textbook on mathematics is an instrument that has a significant effect on the learning practices of mathematics.

The lack of familiarity with the HOTS problem makes it difficult for students to solve the HOTS type of mathematics questions. The students were not used to solving context-based problems such as PISA problems in learning process and evaluation, especially for the high-level problems [47]. This circumstance has two potential implications. First, students with a high degree of interest would find the HOTS form mathematics test a challenge. If they can answer the problem of HOTS mathematics, they will be enthused and inspired to complete other HOTS 
questions. In contrast, students with low interest in mathematics may feel desperate to complete HOTS mathematics questions. They prefer to select the mathematics questions they usually face. Thus, they are not used to answer HOTS mathematics questions [5]. This is in line with Collins [48], who stated that students are more motivated when they are accountable for their learning and are involved in learning activities that require HOTS.

Another study showed that very few of the questions in mathematics textbooks can be classified as HOTS issues. Based on Bloom's taxonomy, less than $10 \%$ of problems, both examples, and exercises in the mathematics textbook can be classified as HOTS issues. Such problems are known as HOTS problems, as they include $\mathrm{C} 4, \mathrm{C} 5$, and $\mathrm{C} 6$ cognitive verbs based on Bloom's taxonomy. On the other hand, despite having the corresponding verb, the questions for some students are not HOTS questions. For students who are used to solve these issues, questions on cognitive level C4-C6 can no longer be categorized as HOTS. The students did not solve the problems using HOTS, but they used algorithmthinking skills.

Moreover, the reliance of mathematics teachers on the task of textbooks is also common in several other countries. Several studies have shown that teachers appear to rely primarily on textbooks in their classrooms. Teachers must also change the tasks of textbooks to plan for innovative education in mathematics classrooms [43]. Mathematics teachers in Indonesia must also improve the standard of mathematics questions, for example, PISA questions. This question focusses on questions based on problem-solving, which is a form of integration in real-life. These problems that help students build their HOTS are not limited to algorithmic reasoning and memory.

The survey indicates that some mathematics teachers have sought to improve the standard of the questions in the textbook. Some of the attempts that teachers have made to this end involve, but are not limited to, changing questions, and searching from other outlets, such as the Internet. Unfortunately, this kind of issue only applies to students who have high performance. This is consistent with the statements by Zohar and Dori [49], which notes that teachers frequently assume that stimulating HOTS is only suitable for high-performing students. According to this view, low-level students are generally unable to cope with tasks that need HOTS and should therefore be spared for irritation induced by such tasks. This view can lead teachers to treat students in a nonegalitarian way.

Finally, there is a general agreement that LOTS and HOTS can be differentiated. However, disparities in the background of a student can mean that a situation requiring HOTS by one person can only involve LOTS by another person. Whether or not a task involves HOTS would rely on the student's academic experience. If it is possible for a student to accomplish its aim by extracting information and without the need to interrelate or rearrange this information, then the students' HOTS do not arise [50].

Improving students' HOTS is a collective experience. One teacher of a specific subject cannot alone improve the higher-order thinking skills, and it is a collaborative process between all subjects' teachers and can be taught for all levels of studying [51]. HOTS can be developed in a cumulative fashion as students' progress through their courses, subjects, and other experiences they get from their institutions. In addition, by including their subjects by problem solving, critical thinking and decisionmaking activities will help students enhance their HOTS [14].

\section{Conclusion}

In an effort to increase student HOTS in Indonesia, the use of active learning models and mathematics textbooks are two problems mentioned as the source of the issue. The active learning model is rarely used in mathematics teaching-learning while the use of official textbooks in Indonesian students does not promote the development of students' HOTS. Active learning methods are mostly used for research activities and not for instructional activities. On the other hand, official textbooks do not make rising HOTS easier for students. In the official textbook, the learning processes and questions are not based on HOTS. Nevertheless, an integrated and systemic effort is required for every subject, from basic to tertiary level, to increase student HOTS. 


\section{References}

[1]. Zohar, A., \& Cohen, A. (2016). Large scale implementation of higher order thinking (HOT) in civic education: The interplay of policy, politics, pedagogical leadership and detailed pedagogical planning. Thinking Skills and Creativity, 21, 85-96. https://doi.org/10.1016/j.tsc.2016.05.003

[2]. Saavedra, A. R., \& Opfer, V. D. (2012). Learning 21 st-century skills requires 21 st-century teaching. Phi Delta Kappan, 94(2), 8-13. https://doi.org/10.1177/003172171209400203

[3]. Hopson, M. H., Simms, R. L., \& Knezek, G. A. (2001). Using a technology-enriched environment to improve higher-order thinking skills. Journal of Research on Technology in education, 34(2), 109119. https://doi.org/10.1080/15391523.2001.10782338

[4]. Tanudjaya, C. P., \& Doorman, M. (2020). Examining Higher Order Thinking in Indonesian Lower Secondary Mathematics Classrooms. Journal on Mathematics Education, 11(2), 277-300. https://doi.org/10.22342/jme.11.2.11000.277-300.

[5]. Kusaeri, K., Hamdani, A. S., \& Suprananto, S. (2019). Student readiness and challenge in completing higher order thinking skill test type for mathematics. Infinity Journal, 8(1), 75-86. https://doi.org/10.22460/infinity.v8i1.p75-86

[6]. Martin, L., Thompson, S. D., \& Richards, L. (2008). Online scenarios in FCS college courses: Enhancing critical thinking skills. Journal of family and Consumer Sciences, 100(2), 25-30.

[7]. Miri, B., David, B. C., \& Uri, Z. (2007). Purposely teaching for the promotion of higher-order thinking skills: A case of critical thinking. Research in science education, 37(4), 353-369.

https://doi.org/10.1007/s11165-006-9029-2

[8]. Ramos, J. L. S., Dolipas, B. B., \& Villamor, B. B. (2013). Higher order thinking skills and academic performance in physics of college students: A regression analysis. International Journal of Innovative Interdisciplinary Research, 4(1), 48-60.

[9]. Fatmawati, A., Zubaidah, S., Mahanal, S., \& Sutopo. (2019). Critical thinking, creative thinking, and learning achievement: How they are related. Journal of Physics: Conference Series, 1417(1), 012070. https://doi.org/10.1088/1742-6596/1417/1/012070

[10]. Mumu, J., \& Tanujaya, B. (2019). Measure Reasoning Skill of Mathematics Students. International journal of higher education, 8(6), 85-91. https://doi.org/10.5430/ijhe.v8n6p85

[11]. Andrews, R. (2005). Models of argumentation in educational discourse. Text-Interdisciplinary Journal for the Study of Discourse, 25(1), 107-127. https://doi.org/10.1515/text.2005.25.1.107

[12]. Livingston, J. A. (2003). Metacognition: An Overview. Retrieved from: https://files.eric.ed.gov/fulltext/ED474273.pdf [accessed: 10 May 2021].
[13]. Yee, M. H., Yunos, J. M., Othman, W., Hassan, R., Tee, T. K., \& Mohamad, M. M. (2015). Disparity of learning styles and higher order thinking skills among technical students. Procedia-Social and Behavioral Sciences, 204, 143-152. https://doi.org/10.1016/j.sbspro.2015.08.127

[14]. Abosalem, Y. (2016). Assessment techniques and students' higher-order thinking skills. International Journal of Secondary Education, 4(1), 1. https://doi.org/10.11648/j.ijsedu.20160401.11

[15]. Meijer, P. C., Verloop, N., \& Beijaard, D. (2002). Multi-method triangulation in a qualitative study on teachers' practical knowledge: An attempt to increase internal validity. Quality and quantity, 36(2), 145167.

[16]. Retnawati, H., Djidu, H., Kartianom, A., \& Anazifa, R. D. (2018). Teachers' knowledge about higherorder thinking skills and its learning strategy. Problems of Education in the 21st Century, 76(2), 215.

[17]. Megawati, M., Wardani, A. K., \& Hartatiana, H. (2020). Kemampuan Berpikir Tingkat Tinggi Siswa Smp Dalam Menyelesaikan Soal Matematika Model Pisa. Jurnal Pendidikan Matematika, 14(1), 15-24. https://doi.org/10.22342/jpm.14.1.6815.15-24

[18]. Aliyanti, A. P., Putri, O. R. U., \& Zukhrufurrohmah, Z. (2019). Analisis Kesalahan Representasi Simbolik Mahasiswa Dalam Menyelesaikan Soal High Order Thinking Skill. Analisis Kesalahan Representasi Simbolik Mahasiswa Dalam Menyelesaikan Soal High Order Thinking Skill, 8(3), 382-394. http://dx.doi.org/10.24127/ajpm.v8i3.2265

[19]. Hadi, W., \& Faradillah, A. (2019). The Algebraic Thinking Process in Solving Hots Questions Reviewed from Student Achievement Motivation. AlJabar: Jurnal Pendidikan Matematika, 10(2), 327337. https://doi.org/10.24042/ajpm.v10i2.5331

[20]. Rahayuningsih, S., \& Jayanti, R. (2019). High Order Thinking Skills (HOTS) Students In Solving Group Problem Based Gender. Al-Jabar: Jurnal Pendidikan Matematika, 10(2), 243-250. https://doi.org/10.24042/ajpm.v10i2.4872

[21]. Samritin, S., \& Suryanto, S. (2016). Developing an assessment instrument of junior high school students' higher order thinking skills in mathematics. REiD (Research and Evaluation in Education), 2(1), 92107. https://doi.org/10.21831/reid.v2i1.8268

[22]. Yenusi, T., Mumu, J., \& Tanujaya, B. (2019). Analisis soal latihan pada buku paket matematika SMA yang bersesuaian dengan higher order thinking skill. Journal of Honai Math, 2(1), 53-64. https://doi.org/10.30862/jhm.v2i1.58

[23]. Farib, P. M., Ikhsan, M., \& Subianto, M. (2019). Proses berpikir kritis matematis siswa sekolah menengah pertama melalui discovery learning. Jurnal Riset Pendidikan Matematika, 6(1), 99-117. https://doi.org/10.21831/jrpm.v6il.21396

[24]. Napitupulu, E. E., Suryadi, D., \& Kusumah, Y. S. (2016). Cultivating Upper Secondary Students' Mathematical Reasoning-Ability and Attitude towards Mathematics Through Problem-Based Learning. Journal on Mathematics Education, 7(2), 117-128. 
[25]. Herutomo, R. A., \& Masrianingsih, M. (2019). Pembelajaran model creative problem-solving untuk mendukung higher-order thinking skills berdasarkan tingkat disposisi matematis. Jurnal Riset Pendidikan Matematika, 6(2), 188-199. https://doi.org/10.21831/jrpm.v6i2.26352

[26]. Minarni, A., \& Napitupulu, E. E. (2020). The role of constructivism-based learning in improving mathematical high order thinking skills of indonesian students. Infinity Journal, 9(1), 111-132. https://doi.org/10.22460/infinity.v9i1.p111-132

[27]. Susanto, E., \& Retnawati, H. (2016). Perangkat pembelajaran matematika bercirikan PBL untuk mengembangkan HOTS siswa SMA. Jurnal Riset Pendidikan Matematika, 3(2), 189-197.

https://doi.org/10.21831/jrpm.v3i2.10631

[28]. Ernawati, E. (2016). Pengembangan perangkat pembelajaran matematika berbasis open-ended approach untuk mengembangkan HOTS siswa SMA. Jurnal Riset Pendidikan Matematika,3(2), 209-220. https://doi.org/10.21831/jrpm.v3i2.10632

[29]. Nurmala, R., \& Mucti, A. (2019). Efektivitas Penggunaan LKM Berbasis HOTS (Higher Order Thinking Skills) terhadap Hasil belajar Mahasiswa Pendidikan Matematika. Journal of Honai Math, 2(2), 117-128. https://doi.org/10.30862/jhm.v2i2.67

[30]. Chen, X., \& Li, Y. (2010). Instructional coherence in Chinese mathematics classroom-A case study of lessons on fraction division. International Journal of Science and Mathematics Education, 8(4), 711-735. https://doi.org/10.1007/s10763-009-9182-y

[31]. Madhuri, G. V., Kantamreddi, V. S. S. N., \& Prakash Goteti, L. N. S. (2012). Promoting higher order thinking skills using inquiry-based learning. European Journal of Engineering Education, 37(2), 117-123. https://doi.org/10.1080/03043797.2012.661701

[32]. Maulidia, F., Johar, R., \& Andariah, A. (2019). A Case Study Of Students'creativity in Solving Mathematical Problems Through Problem Based Learning. Infinity Journal, 8(1), 1-10. https://doi.org/10.22460/infinity.v8i1.p1-10

[33]. Ummah, S. K., In'am, A., \& Azmi, R. D. (2019). Creating Manipulatives: Improving Students' Creativity through Project-Based Learning. Journal on Mathematics Education, 10(1), 93-102. https://doi.org/10.22342/jme.10.1.5093.93-102

[34]. Yumiati, Y., \& Noviyanti, M. (2017). Analysis of Mathematic Representation Ability of Junior High School Students in The Implementation of Guided Inquiry Learning. Infinity Journal, 6(2), 137-148. https://doi.org/10.22460/infinity.v6i2.p137-148

[35]. Dina, Z. H., Ikhsan, M., \& Hajidin, H. (2019). The improvement of communication and mathematical disposition abilities through discovery learning model in junior high school. JRAMathEdu (Journal of Research and Advances in Mathematics Education), 4(1), 11-22.

[36]. Suastika, K. (2017). Mathematics learning model of open problem solving to develop students' creativity. International Electronic Journal of Mathematics Education, 12(3), 569-577.
[37]. Lepik, M., Grevholm, B., \& Viholainen, A. (2015). Using textbooks in the mathematics classroom-the teachers' view. Nordic Studies in Mathematics Education, 20(3-4), 129-156.

[38]. Fan, L., Zhu, Y., \& Miao, Z. (2013). Textbook research in mathematics education: development status and directions. ZDM, 45(5), 633-646. https://doi.org/10.1007/s11858-013-0539-x

[39]. Van Zanten, M., \& van den Heuvel-Panhuizen, M. (2018). Opportunity to learn problem solving in Dutch primary school mathematics textbooks. ZDM, 50(5), 827-838. https://doi.org/10.1007/s11858-018-0973-x

[40]. Howson, G. (2013). The development of mathematics textbooks: historical reflections from a personal perspective. ZDM, 45(5), 647-658.

[41]. Fan, L. (2013). Textbook research as scientific research: towards a common ground on issues and methods of research on mathematics textbooks. ZDM, 45(5), 765-777. https://doi.org/10.1007/s11858-013-0530-6

[42]. Wang, J., \& Lu, X. (2018). Selection of content in high school mathematics textbooks: an international comparison. ZDM, 50(5), 813-826. https://doi.org/10.1007/s11858-018-0977-6

[43]. Baker, D., Knipe, H., Collins, J., Leon, J., Cummings, E., Blair, C., \& Gamson, D. (2010). One hundred years of elementary school mathematics in the United States: A content analysis and cognitive assessment of textbooks from 1900 to 2000. Journal for Research in Mathematics Education, 41(4), 383-423.

https://www.jstor.org/stable/41103881

[44]. Sa'idah, N., Yulistianti, H. D., \& Megawati, E. (2019). Analisis instrumen tes higher order thinking matematika smp. Jurnal Pendidikan Matematika, 13(1), 41-54. https://doi.org/10.22342/jpm.13.1.6619.41-54

[45]. Lee, K. H. (2017). Convergent and divergent thinking in task modification: a case of Korean prospective mathematics teachers' exploration. ZDM, 49(7), 9951008. https://doi.org/10.1007/s11858-017-0889-x

[46]. Rezat, S. (2006). The structures of German mathematics textbooks. ZDM, 38(6), 482-487. https://doi.org/10.1007/BF02652785

[47]. Pratiwi, I., Putri, R. I. I., \& Zulkardi. (2019). Long jump in Asian Games: Contexts of PISA-like mathematic problems. Journal on Mathematics Education, 10(1), 81-92. https://doi.org/10.22342/jme.10.1.5250.81-92

[48]. Collins, R. (2014). Skills for the 21st Century: teaching higher-order thinking. Curriculum \& Leadership Journal, 12(14).

[49]. Zohar, A., \& Dori, Y. J. (2003). Higher order thinking skills and low-achieving students: Are they mutually exclusive?. The journal of the learning sciences, 12(2), 145-181. https://doi.org/10.1207/S15327809JLS1202_1

[50]. Lewis, A., \& Smith, D. (1993). Defining higher order thinking. Theory into practice, 32(3), 131-137. https://doi.org/10.1080/00405849309543588

[51]. Sereni, C., \& Massinger, W. N. (2015). Teaching strategies for critical thinking skills. Academic Exchange Quarterly: Saint Leo University, 19(3). 